IZA DP No. 6540

Quit Behavior and the Role of Job Protection

Anne C. Gielen

Konstantinos Tatsiramos

May 2012 


\title{
Quit Behavior and the Role of Job Protection
}

\author{
Anne C. Gielen \\ Erasmus University Rotterdam \\ and IZA \\ Konstantinos Tatsiramos \\ University of Leicester \\ and IZA
Discussion Paper No. 6540
May 2012 \\ IZA \\ P.O. Box 7240 \\ 53072 Bonn \\ Germany \\ Phone: +49-228-3894-0 \\ Fax: +49-228-3894-180 \\ E-mail: iza@iza.org
}

\begin{abstract}
Any opinions expressed here are those of the author(s) and not those of IZA. Research published in this series may include views on policy, but the institute itself takes no institutional policy positions.

The Institute for the Study of Labor (IZA) in Bonn is a local and virtual international research center and a place of communication between science, politics and business. IZA is an independent nonprofit organization supported by Deutsche Post Foundation. The center is associated with the University of Bonn and offers a stimulating research environment through its international network, workshops and conferences, data service, project support, research visits and doctoral program. IZA engages in (i) original and internationally competitive research in all fields of labor economics, (ii) development of policy concepts, and (iii) dissemination of research results and concepts to the interested public.
\end{abstract}

IZA Discussion Papers often represent preliminary work and are circulated to encourage discussion. Citation of such a paper should account for its provisional character. A revised version may be available directly from the author. 
IZA Discussion Paper No. 6540

May 2012

\section{ABSTRACT}

\section{Quit Behavior and the Role of Job Protection*}

Job protection reduces job turnover by changing firms' hiring and firing decisions. Yet the effect of job protection on workers' quit decisions and post-quit outcomes is still unknown. We present the first evidence using individual panel data from 12 European countries, which differ both in worker turnover rates and in the level of job protection. We find that workers are less likely to quit their job in countries with more job protection, but conditional on quitting they receive higher wages. This evidence can be explained by increased mobility costs associated with higher expected risk of post-quit layoff and job mismatch.

JEL Classification: J28, J62

Keywords: institutions, employment protection, labor mobility, job satisfaction, wages

Corresponding author:

Konstantinos Tatsiramos

Department of Economics

University of Leicester

University Road

Leicester, LE1 7RH

United Kingdom

E-mail: k.tatsiramos@le.ac.uk

\footnotetext{
* We thank Pierre Cahuc, Lorenzo Cappellari, Andrew Clark, Claudio Lucifora, Giordano Mion, Fabien Postel-Vinay, Andrew Oswald, seminar participants at IZA, Universita Cattolica in Milan, and conferences of the Bank of Portugal in Porto, CRETE in Milos, EALE in Cyprus, RES in Cambridge and SOLE in Chicago for useful comments. All errors or omissions are our own.
} 


\section{Introduction}

In the literature on Employment Protection Legislation (EPL) there is abundant evidence on the effect of EPL on job turnover, showing that firms respond to the presence of positive firing costs by reducing both hiring and firing (e.g. Nickell, 1978; Bentolila and Bertola, 1990; and Bertola, 1990). Job protection may not only affect firms’ decisions but may also alter workers' job-to-job mobility decisions. However, we are not aware of any study that has paid attention to the link between job protection and workers' quit behavior. This paper fills this void and is motivated by the fact that there are substantial cross-country differences in job-to-job mobility rates (e.g. OECD, 2010), which coexist with variation in the level of employment protection. Given the importance of mobility for the efficiency of the labor market, understanding how EPL relates to workers' mobility has important policy implications.

Job protection may alter workers mobility decisions by affecting the mobility costs associated with a job quit by means of a higher expected risk of future layoff and job mismatch. When employment protection is strong, a job change implies a much higher future layoff risk due to the limited protection in the new job as a result of the probation period. In addition, hiring levels are lower so individuals face a higher risk of future job mismatch because of the reduced opportunities to find an alternative job. Hence, due to the high mobility costs associated with a job change, workers should be less likely to quit their job when job protection is strong even if job quality is low.

By increasing mobility costs, job protection may not only affect the quit intensity but also post-quit outcomes. Workers decide to change jobs if there is a gain in utility associated with this job change. However, the magnitude of these gains may vary across countries. When there is more job protection, the required gains associated with a quit are expected to be higher in order 
to balance the loss in job security that follows the job quit and the reduced opportunities for further mobility in the future.

This paper contributes to the literature on job quits by considering EPL as a potential determinant of job quit behavior. We present what we believe to be the first evidence on the relation between job protection and workers' job-to-job mobility decisions, and post-quit outcomes. Furthermore, we provide cross-country evidence for this relationship using individual panel data for 12 countries from the European Community Household Panel (ECHP) for the years 1994-2001.

Our empirical approach is implemented in three steps. First, we investigate the determinants of individual quit decisions focusing on the sensitivity of job-to-job mobility with respect to the level of job quality in each country, which is measured using information on job satisfaction. Second, we consider labor market outcomes (e.g. wages) following a job quit. Exploiting the panel dimension of the data, we are able to identify the effects of interest taking into account the presence of unobserved heterogeneity. Finally, we relate our findings to the level of EPL for permanent jobs (regular contracts) in each country.

We find that a low level of job quality induces individuals in each country to quit, but the magnitude of this effect differs substantially across countries and is negatively related to the strictness of EPL. Workers in countries with less job protection are more responsive to a low quality job. Hence, they are more likely to quit if their job satisfaction is low compared to workers in countries with high levels of job protection. We also find that post-quit labor market outcomes are related to the strictness of employment protection legislation. Workers in countries with more job protection compensate the loss in job security following a job quit with higher wages. This evidence is robust to the inclusion of individual worker fixed effects, different 
definitions of the dependent variable (quit decision) and alternative measures of job protection.

The setup of the paper is the following: section 2 discusses the theoretical foundations that can explain cross-country differences in job mobility rates and the related literature, section 3 discusses the data, our empirical strategy and presents some descriptive statistics, section 4 presents the results, and section 5 concludes.

\section{Theoretical Foundations and Related Literature}

Labor mobility is the result of both the decisions of individuals to change jobs (job quits) as well as the decisions of firms to adjust their workforce through hirings and firings. In order to understand why quit rates differ across countries we focus on individual job quit behavior. However, the choices made by firms regarding their hiring and firing may implicitly affect workers' quit decision as we will discuss below.

\subsection{Job Quit Behavior}

The seminal studies of Burdett (1978) and Burdett and Mortensen (1988) show that job-to-job mobility in the presence of on-the-job search with wage posting occurs when individuals are offered a higher wage job offer than the current job, net of any mobility costs. In this setting, differences in quit rates can be explained by differences in job offer arrival rates and/or by different mobility costs across countries. Both differences may arise in the presence of differences in the level of EPL.

Studies by Nickell (1978), Bentolila and Bertola (1990) and Bertola (1990) show that firms may respond to the presence of positive firing costs by reducing both the level of hirings 
and firings. ${ }^{1}$ Kugler and Pica (2008) provide empirical evidence on the negative relationship between EPL and the hiring rate, while Trevisan (2008) shows that the effect is strongest for hirings in permanent positions since firms may decide to hire fewer workers in permanent jobs and replace those by apprenticeships as to circumvent strict EPL. ${ }^{2}$ A lower hiring level is likely to reduce each worker's probability of receiving a better job offer and thus job-to-job mobility. Therefore, in countries with high levels of job protection workers are expected to be less likely to quit their job.

Alternatively, differences in EPL are also likely to affect the cost of changing jobs. There are at least two ways in which this might occur. First, in the presence of a high level of employment protection quitting implies leaving a protected job - due to the accumulated tenure for a less protected one. The new job will initially have lower protection due to the existence of the probation period and because individuals have not accumulated tenure in the job yet. ${ }^{3}$ Hence, the costs of a job quit in terms of future layoff risks are higher when there is more job protection. Although one may argue that workers prefer to be in a protected job, Clark and Postel-Vinay (2009) show that loosing job protection after a job quit seems to be a significant risk since workers' perceived job security is negatively correlated with EPL strictness, i.e. the positive effect of being protected in the current job is outweighed by the negative effect of protection on future job finding possibilities.

A second way in which EPL may affect the costs of a job quit has to do with ex-ante unobservable job quality. Workers may not know ex-ante whether the new job offered is better than their current job in terms of non-monetary aspects (as assumed by Burdett, 1978), but they

\footnotetext{
${ }^{1}$ Abraham and Houseman (1994) have shown that firms may develop alternative strategies such as adjusting working hours to compensate the restricted employment flexibility they face due to job security regulations.

${ }^{2}$ OECD data for European countries show a negative relationship between vacancy rates and the level of EPL (see Table A1).

${ }^{3}$ Higher tenure also implies longer notice periods and higher severance pay in case of layoff.
} 
have to experience how the new job matches their skills and needs (Jovanovic, 1979). If the new job turns out to be a poor match, individuals in countries with a high level of employment protection may have more difficulties to find an alternative job due to the reduced level of hirings. Hence, in the presence of strong EPL, the costs of a job quit may not only be higher in terms of future layoff risks but also in terms of a higher risk of future job mismatch.

\subsection{Post-Quit Outcomes}

The effect of a job quit on post-quit outcomes such as wages is ambiguous. In the model with onthe-job search and wage posting workers quit their job when they receive a higher wage offer. So we should expect a positive wage gain after a quit. Although wage posting models suggest that individuals only quit their job if they are being offered a higher wage, Postel-Vinay and Robin (2002) and Cahuc et al. (2006) show that job-to-job mobility might not necessarily lead to an instant wage gain. Relaxing the assumption that wages are equal within a firm and allowing wage negotiations by way of counter-proposals by firms to workers who might quit, workers may want to accept a current wage cut by moving to a new job that offers better future opportunities. Alternatively, they might stay in the job after receiving a wage increase which matches the higher outside wage offer option.

These future opportunities are more likely to occur in countries with less stringent EPL due to a higher job offer arrival rate related to more hirings, which means that moves with lower wage gains or even wage cuts are possible. In addition, given that stayers are more likely to experience wage gains, the difference in wage gains between quitters and stayers might be lower. In countries with more job protection, instead, job-to-job mobility with wage cuts is less likely to occur and stayers are less likely to experience wage increases due to lower job offer arrival rates. This suggests that wage gains might be more likely when the level of EPL is high. 
It is important to note, however, that the possibility to obtain a higher wage after a job quit may be limited by the fact that high employment protection leads to more wage compression (Koeninger et al., 2007). In addition, worker selection might also affect the relationship between the level of EPL and wage gains. On the one hand, workers in high EPL countries might be reluctant to leave their job as this can be perceived as a signal of low ability ("lemons effect") and those who do quit will receive a lower wage. On the other hand, workers in high EPL countries are facing higher mobility costs because once they move they lose their job security and face higher layoff and future job mismatch risks. Given that the new firm will learn about worker productivity once they are in the new job, the low quality workers will take this into account and they will be less likely to quit their current job.

The interaction of job protection and quit decisions leads to two main hypotheses. First, for a given low level of job quality, there should be less quits and lower job-to-job mobility when EPL is more stringent due to higher mobility costs. Second, the theoretical predictions concerning the immediate wage gains associated with a job quit are ambiguous. On the one hand,

they are expected to be higher when there is more job protection in order to balance the loss in job security that follows the quit decision and the reduced opportunities for further mobility in the future. On the other hand, in countries with high level of employment protection due to more wage compression the immediate wage gains are expected to be lower.

\subsection{Related Literature}

Using job satisfaction as a measure for the quality of a job, earlier studies have shown that workers quit their job if they are not satisfied with their current job (Freeman, 1978; Clark et al., 1998; Clark, 2001), and that job quits typically lead to progress in workers' careers, pay and job satisfaction (e.g. Perez and Rebollo, 2005; Connolly and Gottschalk, 2008; Gielen, 2008). A 
typical pattern of satisfaction with the job is presented in Figure 1, which shows the poor situation in the year before the quit and the improvement the year after.

Although these patterns appear in studies for a number of countries, so far no attention has been paid to understanding the differences in quit rates across countries and the extent to which they can be related to differences in the level of employment protection. Earlier studies show that EPL reduces job turnover (Garibaldi, 1998; Mortensen and Pissarides, 1999; Gomez-Salvador et al., 2004), especially in industries in which employment levels are intrinsically more volatile (e.g. Haltiwanger et al., 2006; Messina and Vallanti, 2007; Micco and Pages, 2006). Some studies find similar negative effects for labor turnover (Kugler and Pica, 2008; Boeri and Jimeno, 2005), though this finding is not robust in all countries (Bauer et al., 2007). Alternatively, we can expect to find positive effects of employment protection on labor mobility if firms try to circumvent strict dismissal regulations by changing to more flexible contracts (Shivardi and Torrini, 2008; Kahn, 2010). Kahn (2011) shows that temporary workers search harder for a new job than workers on permanent jobs.

In this paper, we extend upon this literature by investigating the determinants of quit behavior for a number of countries that differ in their institutional arrangements regarding job protection. We also consider post-quit labor market outcomes and their interaction with institutional differences.

\section{Data and Descriptive Evidence}

We employ the European Community Household Panel (ECHP) longitudinal data set where we can follow individuals during the period 1994-2001 for 12 countries: Austria, Denmark, The Netherlands, Belgium, Finland, France, United Kingdom, Ireland, Italy, Greece, Spain, and 
Portugal. The questions in this dataset are harmonized to allow comparative studies across countries. Our sample consists of male workers aged between 25 and 55 years old, who are observed to be in permanent paid employment for at least two consecutive years. We focus on permanent employment because this is the most common form of employment in all countries. Considering both permanent and fixed-term jobs does not lead to any qualitative differences in our results. Due to differences, however, in the prevalence of fixed-term employment across countries, a separate analysis by type of contract is not feasible due to small sample sizes.

The data provide information about the start date of the current job and the end date of the previous job. Based on this information we define quits as those job changes that occurred in the past year for "obtaining a better or more suitable job", which is based on self reported information about the reasons for leaving the previous job. Our analysis is based on the comparison between job quitters and "job stayers", the latter being those individuals who have not changed their job in the past year. Individuals who have changed their job for reasons other than to obtain a better job (layoff, end of contract, sale or closure of own family business) are left out of the sample. However, this is a quite small fraction so including them in the control group of stayers does not affect our results.

We use two different variables to identify the quality of a job. First, we use information on job satisfaction, which is reported every year at the time of the interview for all the employed individuals in our sample. The typical question asked is the following: "How satisfied are you with your work or main activity.... Using the scale 1 to 6, please indicate your degree of satisfaction. Position 1 means that you are not satisfied at all, and 6 that you are fully satisfied." Another measure of job quality that we use is the hourly wage, which is obtained from the monthly earnings divided by the number of hours worked per month. 
Information about employment protection legislation is taken from the OECD. In particular, we use the EPL-indicator for regular contracts, as this measure is most relevant for workers in permanent jobs deciding about a potential job quit. This indicator varies from 0 (least stringent) to 6 (most restrictive). ${ }^{4}$ The southern European countries are characterized by relatively stringent EPL, along with France and Germany. The United Kingdom, at the far other extreme, is characterized by the least restrictive EPL.

Table 1 presents some summary statistics. The first row of Table 1 shows average quit rates for the 12 countries in our sample. It appears that there are substantial differences in annual quit rates ranging from 1.8 percent in Italy to 10.7 percent in the UK. Figure 2 shows how these cross-country differences in quit rates are correlated with the strictness of employment protection in a country. We observe a negative correlation, which suggests that countries with strong job protection are associated with lower quit rates. The highest quit rates are observed for the U.K. and Denmark, which are also the countries with the lowest levels of job protection. This is suggestive evidence in favor of our first hypothesis that EPL increases the costs associated with job quits, therefore the number of job quits is expected to be lower in high EPL countries. The other rows in Table 1 present averages for the other control variables that are included in our estimations in the next section.

\section{Empirical Analysis and Results}

The empirical analysis is implemented in three steps. First, we investigate the determinants of the individual quit decision focusing on the sensitivity of job-to-job mobility with respect to the value of the current job. Second, we focus on labor market outcomes following a job quit. The analysis in both cases is implemented separately by country, which provides individual estimates

\footnotetext{
${ }^{4}$ For more details see www.oecd.org/employment/protection.
} 
of the relevant effects for each country. Exploiting the panel dimension of the data we are able to identify the effects taking into account the presence of unobserved heterogeneity. Third, we associate the country-specific marginal effects of job value on quit decisions and the marginal effects of quits on post-quit labor market outcomes with the EPL indicator for permanent jobs. Therefore, we are able to provide evidence on the correlation between the effects identified at the individual level and institutional differences, which has not been done in the past.

\subsection{Quit Behavior}

We start by investigating the determinants of the decision to quit and in particular the extent to which the value of the job affects job-to-job mobility. We use standardized job satisfaction as a measure of the value of the job. ${ }^{5}$ For each of the 12 countries, we estimate the following model:

$$
\operatorname{Pr}\left(\text { Quit }_{i, t+1}=1\right)=\beta_{1} X_{i, t}+\beta_{2} J S_{i, t}+\varepsilon_{i, t}^{q},
$$

where Quit is a dummy variable equal to 1 if the individual $i$ quits his job between the year $t$ and $t+1$. The vector $X$ includes individual and job characteristics and the variable $J S$ captures the standardized level of job satisfaction. All these variables are measured in year $t$ before the quit occurred. Finally, $\varepsilon^{q}$ denotes the error term.

Panel A.I. of Table 2 presents the results from the estimation of equation (1) using a linear probability model (LMP). The estimated coefficients for job satisfaction $\beta_{2}$ indicate that, overall, higher levels of job satisfaction are associated with a lower probability to quit. This evidence is consistent with the existing literature (e.g. Clark et al., 1998). There is, however, substantial variation in the effect of job satisfaction on the quit decision across countries. The coefficient (or marginal effect) of the level of job satisfaction is the largest in the UK, Denmark,

\footnotetext{
${ }^{5}$ We standardize the level of job satisfaction to control for the large differences in the variance in job satisfaction across countries.
} 
Finland and Ireland, followed by Belgium, Austria, Spain, Netherlands and France. For all these countries the effect is negative and statistically significant. In contrast, for Greece, Italy and Portugal we find that employed individuals do not respond to the level of job satisfaction. This implies that they are more likely to experience a low level of job satisfaction before they decide to quit compared to workers in other countries.

Note that these results might be biased if there are unobserved time-invariant characteristics which affect both the probability to quit and the level of job satisfaction. For example, more able and better motivated individuals are more likely to find a good job match in which they are more satisfied and less likely to quit. Hence, if unobserved characteristics are not taken into account, this creates a negative correlation between job satisfaction and quits, which leads to a downward bias. Exploiting the panel dimension of the data we are able to control for unobserved heterogeneity by estimating a fixed effects model. The results are presented in Panel A.II. of Table 2. We observe that for most countries the fixed effect estimates of job satisfaction are larger in absolute value than the ones from the linear probability model. The main conclusion, however, remains unchanged as we still find that job satisfaction does not have an effect on quit behavior in Greece and Portugal. For Italy, we find a marginally significant negative effect which is low: a one standard deviation drop in job satisfaction increases the probability to quit by only 0.4 percentage points, which implies an increase in the quit rate of about 22 percent. In Denmark, Finland and the UK, a corresponding drop in job satisfaction increases the probability to quit by about 3 percentage points, which implies an increase of 33 percent on the quit rate in the UK, and a 53 and 74 percent increase in Denmark and Finland, respectively. ${ }^{6}$

In order to understand these differences in quit behavior, Figure 3 plots the estimated

\footnotetext{
${ }^{6}$ A complete set of estimation results for the linear probability model are presented in Table A2.
} 
marginal effects for job satisfaction from the fixed effects job quit model against the strictness of EPL in each country. ${ }^{7}$ We observe that there is a negative relationship between EPL and the sensitivity of the quit decision with respect to job quality. ${ }^{8}$ This relationship suggests that when there is strong job protection workers are less likely to quit even if the quality of their job is lower. Based on the discussion in Section 2, there are two ways to interpret these findings. First, it is possible that the costs associated with the decision to quit are higher in countries with more job protection. Second, because of the lower job offer arrival in countries with high levels of EPL - as a result of less hiring on the side of the firms - workers have to wait longer before a good job offer arrives.

\subsection{Sensitivity Analysis}

We investigate the robustness of our results in a number of ways. First, we consider the effect of job satisfaction on the decision to quit by job tenure. Since low tenure workers are less protected, we expect that they will be less sensitive to the level of job protection. We estimate equation (1) by interacting job satisfaction with a dummy which is equal to one for workers with tenure up to and including six months and a dummy which is equal to one for those with tenure above six months. With this specification we can identify the effect of job satisfaction separately for the two sub-groups of workers (i.e. recent hires versus slightly more established workers). We choose the threshold of six months as this is typically the duration of probation in most countries. The estimates presented in Panels B.I. and B.II. of Table 2 show that the effects of job satisfaction on the decision to quit for workers with tenure above 6 months are very similar to the

\footnotetext{
${ }^{7}$ We transform the marginal effects by multiplying their absolute value by 100 in Figure 3 and the fitted line shown in the Figure is weighted by the inverse of the variance of the coefficients. The same weighting applies to Figures 4 and 5.

${ }^{8}$ Bootstrap analyses show that the effects for the countries with lower levels of job protection (e.g. Denmark, UK, Finland) are significantly different from the effects for the countries with higher levels of job protection (e.g. Netherlands, Portugal).
} 
main results reported in Panel A.II. Figure 4a illustrates the relationship with EPL. The left graph shows no correlation between the effect of job satisfaction on quitting and EPL for workers with tenure less than six months. The right graph of Figure 4a for workers with tenure above six months suggests that the negative relationship between job satisfaction and quitting with EPL is relevant for workers in more established employment relationships, which are those jobs for which EPL is most protective. ${ }^{9}$

Second, we investigate the sensitivity of our main findings with respect to the quit definition. In order to confirm that our results are indeed related to a voluntary job quit, we consider the effect of job satisfaction on the probability to change jobs for other reasons (layoff or other separations). Panels C.I. and C.II. of Table 2 show that, for most countries, higher job satisfaction does not only reduce the probability to quit but also the probability to be laid off. Note, however, that these effects are much smaller than the effects on job quitting. Observing a small negative effect of job quality - measured by job satisfaction - on the probability to change jobs through a layoff is intuitive because better matches are less likely to be destroyed. For some countries, the probability of having a separation due to other reasons also reduces. Figure 4b illustrates how these results are associated with EPL. We find in the left graph of Figure 4b that the effect of job satisfaction on the layoff probability is also negatively correlated with the EPL index but the correlation is much weaker compared to the quit decision. This negative relationship is not surprising given that a higher level of employment protection is associated with fewer layoffs. Interestingly, although the effect of job satisfaction on other separations is also negative, the variation across countries is not correlated with the level of employment protection as can be seen in the right graph of Figure 4b.

The findings that the effect of job satisfaction on quitting is negatively related to EPL

\footnotetext{
${ }^{9}$ We find a similar pattern if we restrict the sample to private sector workers only.
} 
only for more established jobs, for which EPL is more protective, and that the effect on other separations is uncorrelated offers additional evidence for the role of EPL on job mobility.

Finally, we also investigate the sensitivity of the relationship between the quit decision and EPL with respect to different indexes of EPL. In particular, we consider a number of subindexes which are part of the overall EPL index: the index for procedural inconvenience, the index of notice and severance payments, and the index for the difficulty of dismissal. According to our hypothesis stated in section 2, we expect the index for the difficulty of dismissal to explain most of the differences in quit behavior across countries. Figure 5 shows for all sub-indexes a negative relationship of the quit decision with EPL, with the strongest one for the index related to the difficulty of dismissal (based on the reported $R^{2}$ ).

\subsection{Post-Quit Outcomes}

We now turn to the second part of our empirical analysis to investigate whether the differences in quit behavior affect labor market outcomes once the job quit has been realized. We consider both subjective job satisfaction and the hourly wage, a more objective measure of job quality.

\subsubsection{Post-Quit Job Satisfaction}

We start by looking at potential differences across countries in job satisfaction after the job quit. On the one hand, individuals in countries with high levels of employment protection may exhibit lower levels of post-quit job satisfaction since their pre-quit job satisfaction was also lower. In addition, the layoff risk after the move to a new job is higher, which might also affect the level of job satisfaction negatively. On the other hand, individuals in countries with high levels of job protection may face a higher risk of future job mismatch and, therefore, they may only decide to 
accept a new job if they are certain that this will be a good match. Hence, due to these offsetting effects, post-quit job satisfaction levels might differ across countries but the differences are not expected to be related in a systematic way to differences in EPL. For each of the 12 countries we estimate the following model:

$$
J S_{i, t}=\gamma_{1} X_{i, t}+\gamma_{2} Q_{i, t}+\varepsilon_{i, t}^{J S},
$$

where $J S$ is the standardized level of observed job satisfaction in a given year, $X$ is a vector of individual and job characteristics, $Q$ is a dummy variable equal to 1 if the individual has quit his job between the year $t-1$ and $t$, and $\varepsilon^{J S}$ is the error term.

Panel A.I. of Table 3 presents the results from estimating equation (2) by OLS. The parameter estimates for the quit dummy $\left(\gamma_{2}\right)$ suggest that those who quit experience higher levels of job satisfaction compared to stayers. This effect is statistically significant in almost all countries. We also estimate equation (2) with fixed effects and we present the estimated coefficient for the quit dummy in Panel A.II. of Table 3. The results confirm the finding that quitters experience higher levels of job satisfaction compared to stayers. ${ }^{10}$

The magnitude of the effect varies across countries with a 0.55 standard deviation higher level of job satisfaction for quitters in Finland, 0.5 in Belgium, about 0.3 in Austria and France, about 0.25 in Spain, Italy and Ireland, and lower and non-significant effects for Denmark, Greece, Netherlands and Portugal.

The top graph in Figure 6 plots the estimated effects from the fixed effects model against the strictness of EPL in each country. The results indicate that there is quite some cross-country variation in the post-quit job satisfaction levels, but this does not seem to be related to the level

\footnotetext{
${ }^{10}$ A complete set of estimation results for the linear probability model are presented in Table A3.
} 
of EPL in a systematic way as the fitted line is flat. As we noted earlier the Figure is weighted by the inverse of the variance of the coefficients.

The lack of a relationship between the level of job protection and the level of job satisfaction following a job change suggests that overall quitters obtain a job with a higher value or match quality compared to stayers. However, there might be differential effects on the various job quality domains (i.e. wages and job security) for the different countries, which do not show in overall job satisfaction if they offset each other. We consider this possible offsetting effect below.

\subsubsection{Post-Quit Wages}

Job satisfaction levels following a job quit are different across countries, but not systematically related to cross-country differences in EPL. However, this does not necessarily imply that there are no country differences in post-job quit outcomes. For example, individuals might look for higher wages to compensate for the loss in job security after a quit. Since the loss in job security is positively related with EPL (Clark and Postel-Vinay, 2009), the observed wage following a job quit might also vary with the level of employment protection. If this is the case, then the drop in job security following a quit might be offset by higher wages. This could explain our finding of no relationship of overall job satisfaction and differences in job protection.

In order to disentangle the two effects, we consider the effect of job quits on wages by estimating for each country the following equation:

$$
\log W_{i, t}=\delta_{1} X_{i, t}+\delta_{2} Q_{i, t}+\varepsilon_{i, t}^{W},
$$

where $W$ is the hourly wage, $Q$ is a dummy variable equal to 1 if the individual has quit his job between the year $t-1$ and $t$, and $\varepsilon^{W}$ is the error term. 
Panel B.I. of Table 3 presents the results of estimating equation (3). The estimates of the coefficient $\delta_{2}$ show that in most countries quitters receive higher wages than stayers. This finding is robust to the inclusion of individual fixed effects. From panel B.II. of Table 3 it appears that the largest effect (nearly 7 percent) is observed in Portugal, which is also the country with the strongest employment protection for permanent jobs. Note that the quit effect on wages for workers in the UK and Denmark, the countries with the lowest levels of job protection, are not significant. ${ }^{11}$ The bottom graph of Figure 6 plots the coefficients of the quit dummy against the EPL strictness and shows an upward sloping trend. This suggests that workers in countries with high levels of job protection, who experience lower levels of job security after a job quit, end up in jobs in which they receive higher wages than workers in countries with low level of protection. These higher wages are likely to compensate for the loss in job security. ${ }^{12}$

Although we find a positive slope of the effect of quit on wages with the level of EPL across countries, the effect is not significant for many countries and there are no significant differences across countries. This might be due to the fact that employment protection policies and wage compression policies are often implemented together (Bertola and Rogerson, 1997), which means that wage following a job quit will be lower when job protection is high. This might reduce the effect of quitting on wages in countries with high levels of EPL, which are necessary in order to compensate for the lower levels of job security.

\section{Conclusion}

This paper investigates the relationship between employment protection legislation and workers’

\footnotetext{
${ }^{11}$ A complete set of estimation results for the linear probability model are presented in Table A4.

${ }^{12}$ Similar to the quit decision we find a similar pattern if we restrict the sample to private sector workers only.
} 
labor market behavior. In particular, we examine the extent to which cross-country differences in individual quit behavior can be explained by the existing differences in the level of job protection across countries. By focusing on workers' quit decision we contribute to the existing literature, which has mainly focused on the effect of EPL on firms' hiring and firing decisions.

We use individual panel data from 12 European countries, which differ in their level of job protection. We find that the effect of job quality as measured by the level of job satisfaction, on the decision to quit differs across countries and is negatively related to the level of employment protection. This finding suggests that, in countries with high levels of job protection, workers are less likely to quit their job even if job quality is low. This can explain the negative relationship between quit rates and EPL across countries that we observe in the data. This individual behavior can be explained by increased mobility costs associated with higher expected risk of post-quit layoff and job mismatch when the level of job protection is high. Furthermore, we find that postquit labor market outcomes are also related to EPL. Individuals in countries with a high level of employment protection, who experience lower levels of job security after a job quit, end up in jobs in which they realize slightly higher wages than workers in countries with low level of protection.

Considering these findings together suggest that more job protection lowers quit rates by inducing the employed workers to stay in low satisfaction jobs until they find a better paying job, which is necessary for offsetting the increased risks of mobility. Hence, if policy makers decide to impose strong employment protection legislation to protect workers from involuntary layoff, this comes at a cost of reduced voluntary labor mobility.

These correlations between individual quit behavior and EPL that we report should not be interpreted as a causal effect of EPL. Giving a causal interpretation would require sufficient 
exogenous variation in EPL for all the countries simultaneously during the period 1994-2001, for which panel data are available. In the absence of such variation, the analysis presented in this paper is a first step towards understanding the role of job protection in individual job quit behavior. The analysis of the causal effect of changes in job protection on the decision to quit and post-quit outcomes is the subject of future research. 


\section{References}

Abraham, K. and S. Houseman (1994). Does Employment Protection Inhibit Labor Market Flexibility? Lessons from Germany, France and Belgium. In R. Blank (Ed.), Social protection versus Economic Flexibility, pp. 59-93. Chicago: University of Chicago Press.

Bauer, T., S. Bender, and H. Bonin (2007). Dismissal Protection and Workers Flows in Small Establishments. Economica 74, 804-821.

Bentolila, S. and G. Bertola (1990). Firing Costs and Labor Demand: How Bad is Eurosclerosis? Review of Economic Studies 57, 381-402.

Bertola, G. (1990). Job Security, Employment and Wages. European Economic Review 34, 851886.

Bertola, G. and R. Rogerson (1997). Institutions and Labor Reallocation. European Economic Review 41, 1147-1171.

Boeri, T. and J. Jimeno (2005). The Effects of Employment Protection: Learning from Variable Enforcement. European Economic Review 49, 2057-2077.

Burdett, K. (1978). A Theory of Employee Job Search and Quit Rates. American Economic Review 68(1), 212-220.

Burdett, K. and D. Mortensen (1998). Wage Differentials, Employer Size and Unemployment. International Economic Review 39, 257-273.

Cahuc, P., F. Postel-Vinay, and J.-M. Robin (2006). Wage Bargaining with On-the-Job Search: Theory and evidence. Econometrica 74(2), 323-364.

Clark, A. (2001). What Really Matters in a Job? Hedonic Measurement using Quit Data. Labour Economics 8, 223-242. 
Clark, A., Y. Georgellis, and P. Sanfey (1998). Job Satisfaction, Wage Changes and Quits: Evidence from Germany. Research in Labor Economics 17, 95-121.

Clark, A. and F. Postel-Vinay (2009). Job Security and Job Protection. Oxford Economic Papers 61, 207-239.

Connolly, H. and P. Gottschalk (2008). Wage Cuts as Investment in Future Wage Growth. Labour 22, 1-22.

Freeman, R. (1978). Job Satisfaction as an Economic Variable. American Economic Review 68(2), 135-141.

Garibaldi, P. (1998). Job Flow Dynamics and Firing Restrictions. European Economic Review 42, 245-275.

Gielen, A.C (2008). Age-Specific Labor Market Dynamics. CentER Dissertation Series 204. Tilburg: Tilburg University.

Gomez-Salvador, R., J. Messian, and G. Vallanti (2004). Gross Job Flows and Institutions in Europe. Labour Economics 11, 469-485.

Haltiwanger, J., S. Scarpetta, and H. Schwieger (2006). Assessing Job Flows Across Countries: The Role of Industry, Firm Size and Regulations. IZA Discussion Paper No. 2450.

Jovanovic, B. (1979). Job Matching and the Theory of Turnover. Journal of Political Economy 87, 972-990.

Kahn, L. M. (2010). Employment Protection Reforms, Employment and the Incidence of Temporary Jobs in Europe: 1996-2001. Labour Economics 17, 1-15.

Kahn, L. M. (2011). Temporary Jobs and Job Search Effort in Europe. mimeo.

Koeninger, W., M. Leonardi, and L. Nunziata (2007). Labor Market Institutions and Wage Inequality. Industrial \& Labor Relations Review 60 (3), 340-356. 
Kugler, a. and G. Pica (2008). Effects of Employment Protection on Worker and Job Flows:

Evidence from the 1990 Italian Reform. Labour Economics 15, 78-95.

Messina, J. and G. Vallanti (2007). Job Flow Dynamics and Firing Restriction: Evidence from Europe. Economic Journal 117, F279-F301.

Micco, A. and C. Pages (2006). The Economic Effects of Employment Protection: Evidence from International Industry-Level Data. IZA Discussion Paper No. 2433.

Mortensen, D. T. and C. Pissarides (1999). Unemployment Responses to Skill Biased Shocks:

The Role of Labor Market Policy. Economic Journal 109, 242-265.

Nickell, S. (1978). Fixed Costs, Employment and Labour Demand over the Cycle. Economica 1, 329-345.

OECD (2010). Institutional and Policy Determinants of Labour Market Flows. In Employment Outlook, pp. 167-210. Paris: OECD.

Perez, J. I. and Y. S. Rebollo (2005). Wage Changes Through Job Mobility in Europe: A Multinomial Endogenous Switching Approach. Labour Economics 12 (4), 531-555.

Pfann, G. A. (2001). Options to Quit. Economics Letters 70, 259-265.

Postel-Vinay, F. and J.-M. Robin (2002). The Distribution of Earnings in an Equilibirum Search Model with State-Dependent Offers and Counter-Offers. International Economic Review 43 (4), 989-1016.

Schivardi, F. and R. Torrini (2008). Identifying the Effects of Firing Restriction Through SizeContingent Differences in Regulation. Labour Economics 15, 482-511.

Trevisan, E. (2008), "Enforcement of employment protection and the hiring behavior of firms. Evidence from a large Italian region”, DSE Working Paper, nr. 25-08. 
Figure 1. Stylized Figure of Job Satisfaction Around a Job Quit.

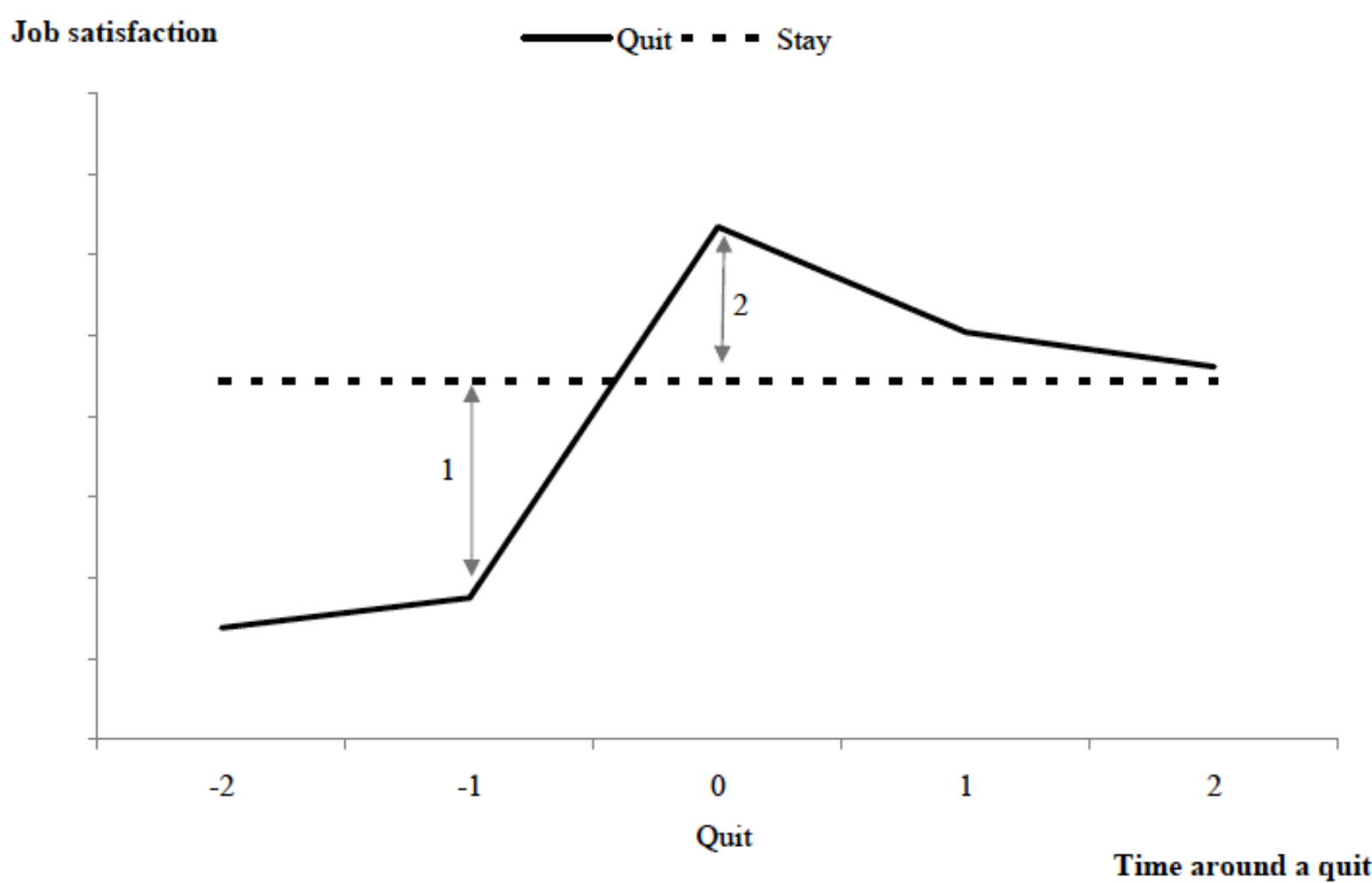

Source: Based on Gielen (2008). 
Figure 2. Average Country Quit Rates and EPL.

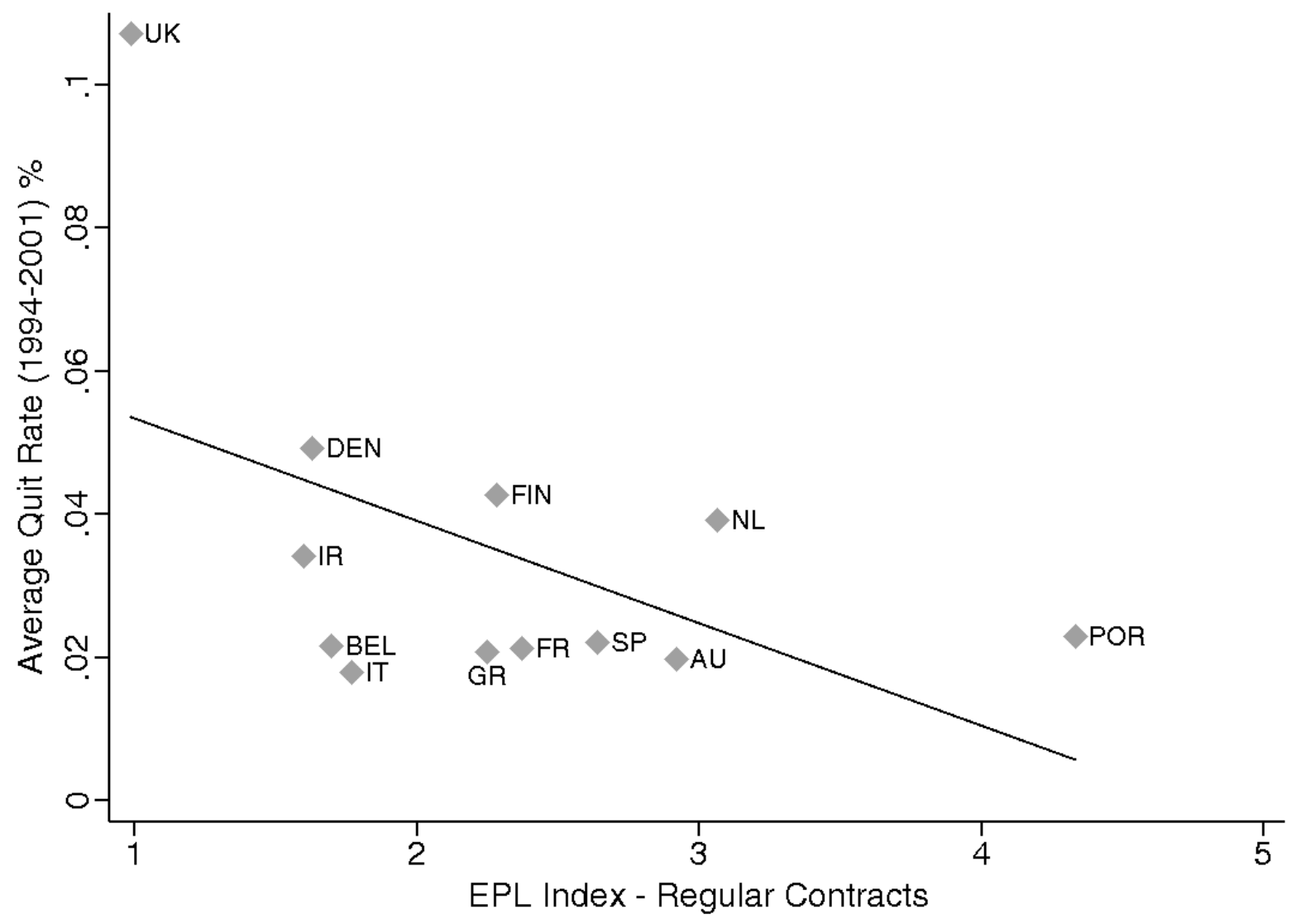

Note: Quit rates are based on individual quits averaged over 1994-2001 from the ECHP. 
Figure 3. Effect of Job Satisfaction on Quit Decision over EPL.

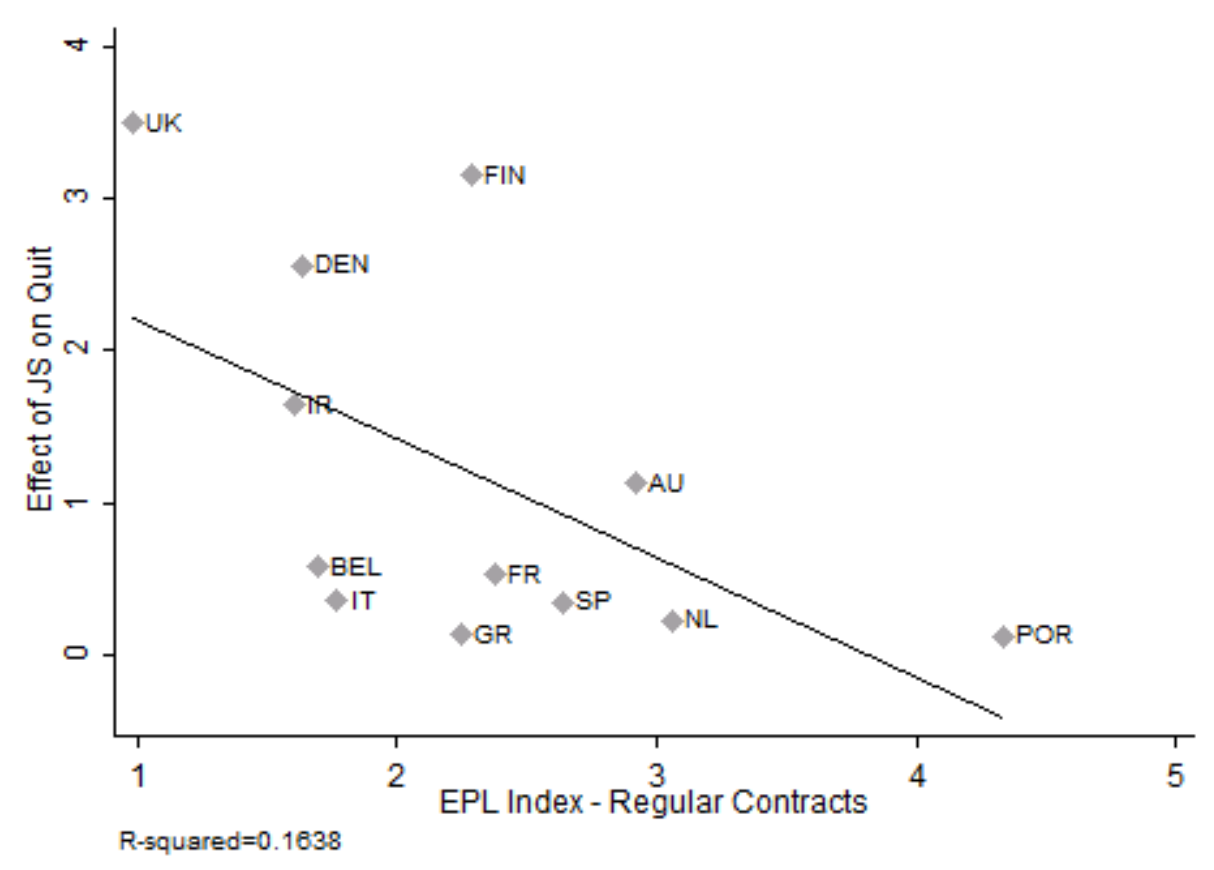

Note: The figure presents the absolute value of each estimate (x 100). The regression is weighted by the inverse of the variance of the point estimates. 


\section{Figure 4. Sensitivity Analysis.}

Figure 4a. Effect of Job Satisfaction on Quit Decision by Tenure over EPL.
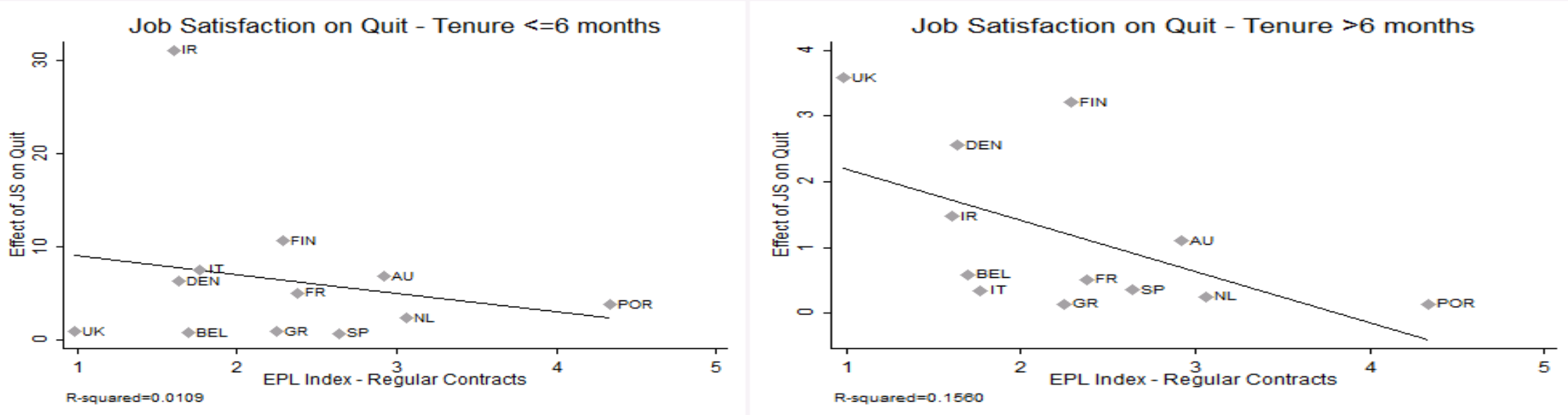

Figure 4b. Effect of Job Satisfaction on Layoff and Other Separations over EPL.
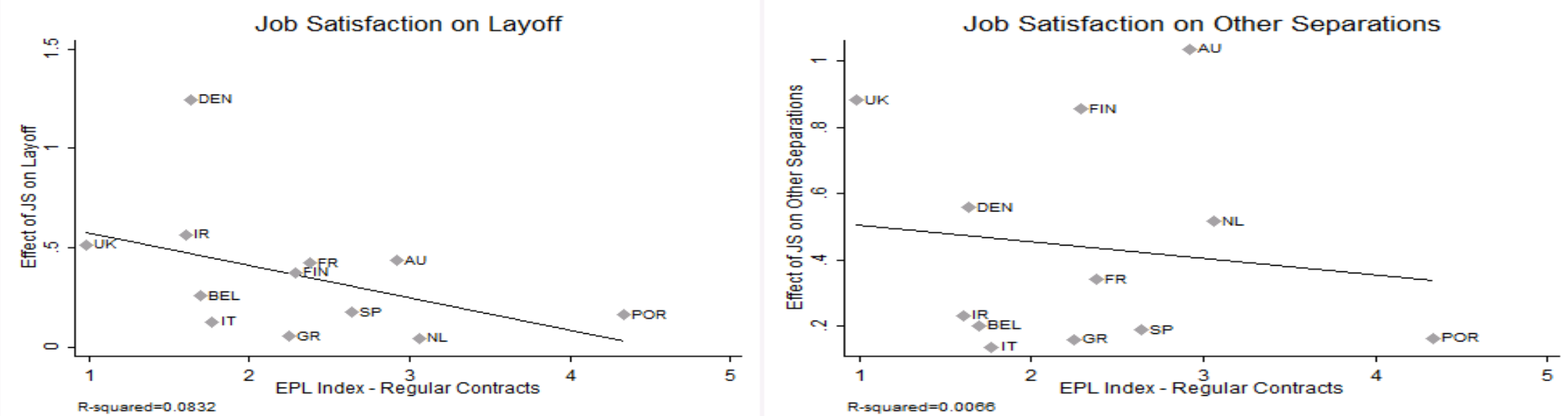

Note: The figures present the absolute value of each estimate (x 100). The regressions are weighted by the inverse of the variance of the point estimates. 
Figure 5. Effect of Job Satisfaction on Quit Decision over Various EPL Sub-Indexes.
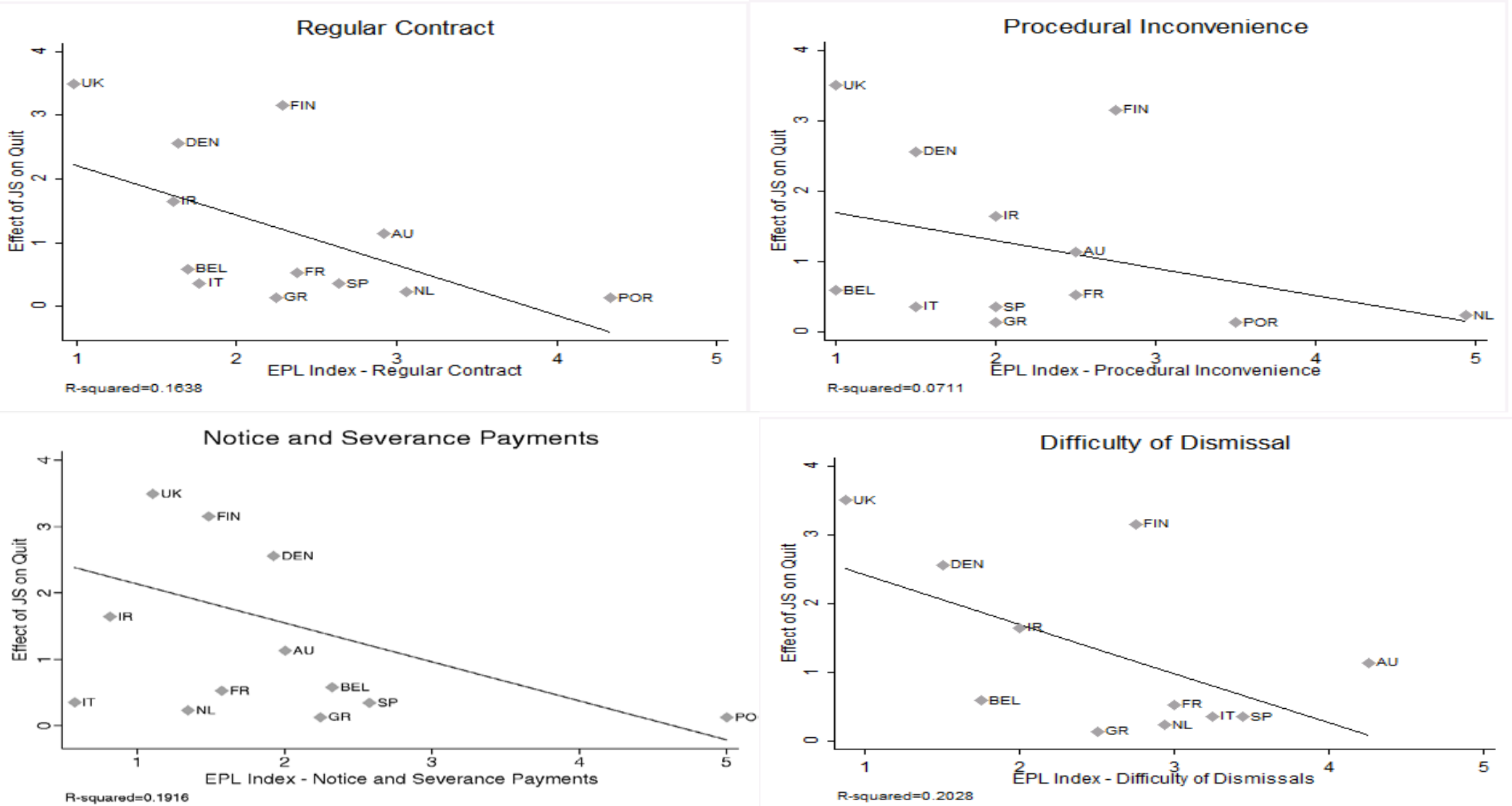

Note: The figures present the absolute value of each estimate (x 100). The regressions are weighted by the inverse of the variance of the point estimates. 
Figure 6. Effect of Quits on Job Satisfaction and Wages over EPL.
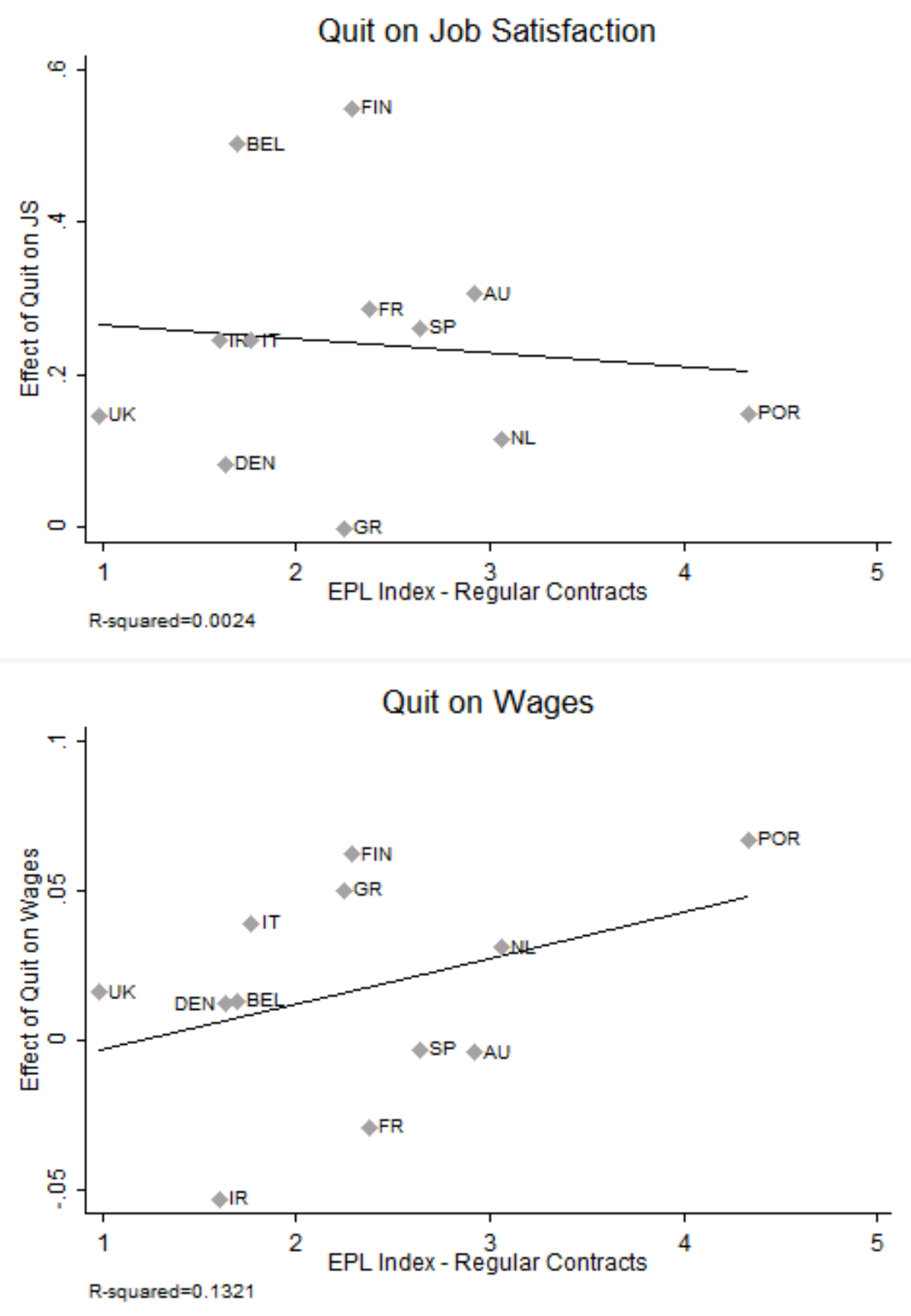

Note: The regressions are weighted by the inverse of the variance of the point estimates. 


\begin{tabular}{|c|c|c|c|c|c|c|c|c|c|c|c|c|}
\hline & \multicolumn{2}{|c|}{ Austria } & \multicolumn{2}{|c|}{ Belgium } & \multicolumn{2}{|c|}{ Denmark } & \multicolumn{2}{|c|}{ Finland } & \multicolumn{2}{|c|}{ France } & \multicolumn{2}{|c|}{ Greece } \\
\hline & Mean & s.d. & Mean & s.d. & Mean & s.d. & Mean & s.d. & Mean & s.d. & Mean & s.d. \\
\hline Quit & 0.020 & 0.140 & 0.022 & 0.146 & 0.049 & 0.216 & 0.043 & 0.202 & 0.021 & 0.145 & 0.021 & 0.143 \\
\hline Job Satisfaction & 4.929 & 0.921 & 4.474 & 1.150 & 4.947 & 0.881 & 4.556 & 0.954 & 4.395 & 0.996 & 4.195 & 1.061 \\
\hline Elapsed Tenure (months) & 154.232 & 79.418 & 145.139 & 76.629 & 119.704 & 78.507 & 125.200 & 76.860 & 140.165 & 78.853 & 145.698 & 83.138 \\
\hline Age & 39.593 & 7.764 & 39.936 & 7.321 & 41.082 & 7.809 & 40.944 & 7.820 & 40.602 & 7.699 & 40.419 & 7.812 \\
\hline Secondary Education & 0.804 & 0.397 & 0.327 & 0.469 & 0.458 & 0.498 & 0.448 & 0.497 & 0.377 & 0.485 & 0.371 & 0.483 \\
\hline Lower than Sec. Education & 0.112 & 0.315 & 0.232 & 0.422 & 0.133 & 0.340 & 0.170 & 0.376 & 0.401 & 0.490 & 0.296 & 0.457 \\
\hline Couple & 0.787 & 0.410 & 0.871 & 0.335 & 0.842 & 0.365 & 0.843 & 0.364 & 0.874 & 0.332 & 0.816 & 0.388 \\
\hline Foreign Born & 0.049 & 0.217 & 0.082 & 0.274 & 0.024 & 0.152 & 0.036 & 0.186 & 0.080 & 0.271 & 0.040 & 0.196 \\
\hline Number of Children & 0.526 & 0.499 & 0.508 & 0.500 & 0.535 & 0.499 & 0.533 & 0.499 & 0.593 & 0.491 & 0.593 & 0.491 \\
\hline Private Job & 0.685 & 0.465 & 0.633 & 0.482 & 0.679 & 0.467 & 0.700 & 0.458 & 0.720 & 0.449 & 0.479 & 0.500 \\
\hline Industry & 0.444 & 0.497 & 0.369 & 0.482 & 0.343 & 0.475 & 0.438 & 0.496 & 0.405 & 0.491 & 0.315 & 0.464 \\
\hline Services & 0.541 & 0.498 & 0.623 & 0.485 & 0.635 & 0.482 & 0.532 & 0.499 & 0.579 & 0.494 & 0.679 & 0.467 \\
\hline Unemployment Experience & 0.138 & 0.345 & 0.139 & 0.346 & 0.220 & 0.415 & 0.267 & 0.442 & 0.133 & 0.340 & 0.163 & 0.369 \\
\hline Regional Unemployment Rate & 4.861 & 1.550 & 10.7054 & 2.858 & 7.903 & 0.075 & 10.331 & 2.767 & 11.103 & 2.104 & 11.561 & 0.609 \\
\hline \multirow[t]{3}{*}{ Number of Observations } & \multicolumn{2}{|c|}{ 4,328 } & \multicolumn{2}{|c|}{ 3,313 } & \multicolumn{2}{|c|}{3,597} & \multicolumn{2}{|c|}{2,203} & \multicolumn{2}{|c|}{7,204} & \multicolumn{2}{|c|}{4,564} \\
\hline & \multicolumn{2}{|c|}{ Ireland } & \multicolumn{2}{|c|}{ Italy } & \multicolumn{2}{|c|}{ Netherlands } & \multicolumn{2}{|c|}{ Portugal } & \multicolumn{2}{|c|}{ Spain } & \multicolumn{2}{|c|}{ UK } \\
\hline & Mean & s.d. & Mean & s.d. & Mean & s.d. & Mean & s.d. & Mean & s.d. & Mean & s.d. \\
\hline Quit & 0.034 & 0.182 & 0.018 & 0.133 & 0.039 & 0.194 & 0.023 & 0.150 & 0.022 & 0.147 & 0.107 & 0.309 \\
\hline Job Satisfaction & 4.637 & 1.113 & 4.160 & 1.183 & 4.757 & 0.838 & 4.141 & 0.833 & 4.427 & 1.137 & 4.197 & 1.252 \\
\hline Elapsed Tenure (months) & 147.671 & 80.731 & 155.699 & 79.604 & 133.110 & 78.977 & 150.033 & 79.046 & 153.060 & 79.280 & 72.710 & 65.213 \\
\hline Age & 39.636 & 7.836 & 40.490 & 7.684 & 40.916 & 7.451 & 39.159 & 7.976 & 40.285 & 7.645 & 39.907 & 7.839 \\
\hline Secondary Education & 0.388 & 0.487 & 0.451 & 0.498 & 0.333 & 0.471 & 0.129 & 0.335 & 0.219 & 0.413 & 0.127 & 0.333 \\
\hline Lower than Sec. Education & 0.323 & 0.468 & 0.425 & 0.494 & 0.517 & 0.500 & 0.796 & 0.403 & 0.447 & 0.497 & 0.340 & 0.474 \\
\hline Couple & 0.801 & 0.400 & 0.823 & 0.382 & 0.899 & 0.301 & 0.835 & 0.371 & 0.855 & 0.353 & 0.827 & 0.378 \\
\hline Foreign Born & 0.038 & 0.190 & 0.019 & 0.135 & 0.001 & 0.037 & 0.023 & 0.150 & 0.011 & 0.102 & 0.004 & 0.061 \\
\hline Number of Children & 0.621 & 0.485 & 0.576 & 0.494 & 0.571 & 0.495 & 0.566 & 0.496 & 0.589 & 0.492 & 0.470 & 0.499 \\
\hline Private Job & 0.592 & 0.492 & 0.620 & 0.485 & 0.735 & 0.441 & 0.737 & 0.440 & 0.698 & 0.459 & 0.774 & 0.418 \\
\hline Industry & 0.356 & 0.479 & 0.381 & 0.486 & 0.323 & 0.468 & 0.406 & 0.491 & 0.373 & 0.484 & 0.398 & 0.489 \\
\hline Services & 0.612 & 0.487 & 0.597 & 0.491 & 0.664 & 0.472 & 0.551 & 0.497 & 0.603 & 0.489 & 0.595 & 0.491 \\
\hline Unemployment Experience & 0.143 & 0.350 & 0.139 & 0.346 & 0.104 & 0.305 & 0.110 & 0.313 & 0.188 & 0.391 & 0.184 & 0.387 \\
\hline Regional Unemployment Rate & 9.572 & 0.826 & 14.111 & 9.025 & 10.148 & 0.000 & 6.608 & 2.040 & 17.071 & 4.723 & 5.170 & 1.427 \\
\hline Number of Observations & \multicolumn{2}{|c|}{2,979} & \multicolumn{2}{|c|}{9,483} & \multicolumn{2}{|c|}{8,143} & \multicolumn{2}{|c|}{6,682} & \multicolumn{2}{|c|}{6,836} & \multicolumn{2}{|c|}{5,350} \\
\hline
\end{tabular}




\begin{tabular}{|c|c|c|c|c|c|c|c|c|c|c|c|c|c|c|c|c|c|c|}
\hline \multirow[b]{2}{*}{$\begin{array}{l}\text { A. Effect on Quits } \\
\text { A.I. LPM }\end{array}$} & \multicolumn{3}{|c|}{ Austria } & \multicolumn{3}{|c|}{ Belgium } & \multicolumn{3}{|c|}{ Denmark } & \multicolumn{3}{|c|}{ Finland } & \multicolumn{3}{|c|}{ France } & \multicolumn{3}{|c|}{ Greece } \\
\hline & Coef. & s.e. & & Coef. & s.e. & & Coef. & s.e. & & Coef. & s.e. & & Coef. & s.e. & & Coef. & s.e. & \\
\hline $\begin{array}{l}\text { Job Satisfaction (Standardized) } \\
\text { A.II. Fixed effects }\end{array}$ & -0.007 & 0.003 & $* * *$ & -0.009 & 0.003 & $* * *$ & -0.018 & 0.005 & $* * *$ & -0.014 & 0.005 & $* * *$ & -0.005 & 0.002 & $* *$ & 0.001 & 0.002 & \\
\hline Job Satisfaction (Standardized) & -0.011 & 0.003 & $* * *$ & -0.006 & 0.004 & & -0.026 & 0.005 & $* * *$ & -0.032 & 0.008 & $* * *$ & -0.005 & 0.002 & $* *$ & 0.001 & 0.003 & \\
\hline \multicolumn{19}{|c|}{ B. Effect on Quits by Tenure (Fixed Effects) } \\
\hline $\begin{array}{l}\text { Job Satisfaction } \\
\text { B.II. More than } 6 \text { months }\end{array}$ & -0.068 & 0.031 & $* *$ & -0.007 & 0.047 & & -0.063 & 0.064 & & 0.106 & 0.093 & & -0.050 & 0.032 & & -0.009 & 0.040 & \\
\hline Job Satisfaction & -0.011 & 0.003 & $* * *$ & -0.006 & 0.004 & & -0.026 & 0.005 & $* * *$ & -0.032 & 0.008 & $* * *$ & -0.005 & 0.002 & $* * *$ & 0.001 & 0.003 & \\
\hline \multicolumn{19}{|c|}{ C. Effect on Other Reasons (Fixed Effects) } \\
\hline \multicolumn{19}{|l|}{ C.II. Other separations } \\
\hline \multirow[t]{2}{*}{ Job Satisfaction } & -0.010 & 0.002 & $* * *$ & 0.002 & 0.003 & & -0.006 & 0.004 & & -0.009 & 0.003 & $* * *$ & -0.003 & 0.001 & $* * *$ & -0.002 & 0.002 & \\
\hline & \multicolumn{3}{|c|}{ Ireland } & \multicolumn{3}{|c|}{ Italy } & \multicolumn{3}{|c|}{ Netherlands } & \multicolumn{3}{|c|}{ Portugal } & \multicolumn{3}{|c|}{ Spain } & \multicolumn{3}{|c|}{ UK } \\
\hline $\begin{array}{l}\text { A. Effect on Quits } \\
\text { A.I. LPM }\end{array}$ & Coef. & s.e. & & Coef. & s.e. & & Coef. & s.e. & & Coef. & s.e. & & Coef. & s.e. & & Coef. & s.e. & \\
\hline $\begin{array}{l}\text { Job Satisfaction } \\
\text { A.II. Fixed effects }\end{array}$ & -0.011 & 0.004 & $* * *$ & -0.002 & 0.002 & & -0.005 & 0.002 & $* *$ & 0.000 & 0.002 & & -0.006 & 0.002 & $* * *$ & -0.023 & 0.005 & $* * *$ \\
\hline Job Satisfaction & -0.016 & 0.005 & $* * *$ & -0.004 & 0.002 & $*$ & -0.002 & 0.003 & & 0.001 & 0.003 & & -0.004 & 0.002 & $*$ & -0.035 & 0.006 & $* * *$ \\
\hline $\begin{array}{l}\text { B. Effect on Quits by Tenure } \\
\text { B.I. Less or equal than } 6 \text { mont }\end{array}$ & xed Effe & & & & & & & & & & & & & & & & & \\
\hline $\begin{array}{l}\text { Job Satisfaction } \\
\text { B.II. More than } 6 \text { months }\end{array}$ & -0.311 & 0.053 & $* * *$ & -0.075 & 0.027 & $* * *$ & 0.023 & 0.032 & & -0.038 & 0.039 & & 0.007 & 0.026 & & -0.009 & 0.028 & \\
\hline Job Satisfaction & -0.015 & 0.005 & $* * *$ & -0.003 & 0.002 & $*$ & -0.002 & 0.003 & & 0.001 & 0.003 & & -0.004 & 0.002 & $*$ & -0.036 & 0.006 & $* * *$ \\
\hline C. Effect on Other Reasons ( & ed Effec & & & & & & & & & & & & & & & & & \\
\hline $\begin{array}{l}\text { C.I. Layoff } \\
\text { Job Satisfaction }\end{array}$ & -0.006 & 0.002 & $* * *$ & -0.001 & 0.001 & & 0.0004 & 0.001 & & 0.002 & 0.001 & & -0.002 & 0.001 & * & -0.005 & 0.003 & \\
\hline C.II. Other separations & & & & & & & & & & & & & & & & & & \\
\hline Job Satisfaction & -0.002 & 0.003 & & 0.001 & 0.001 & & -0.005 & 0.002 & $* *$ & -0.002 & 0.002 & & -0.002 & 0.001 & & -0.009 & 0.004 & $* *$ \\
\hline
\end{tabular}




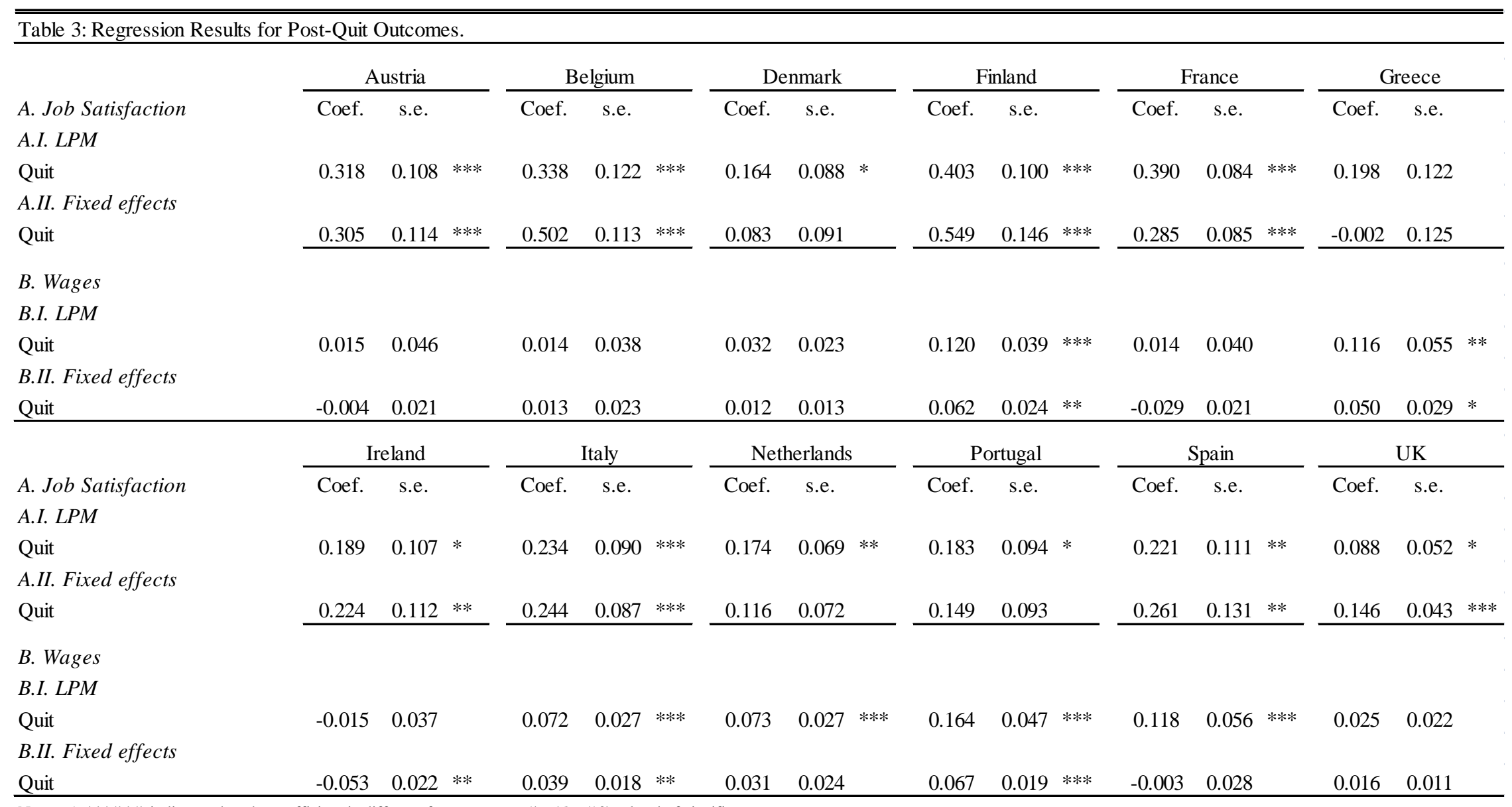


Table A1. EPL and Vacancy Rates.

EPL

Regular Contracts (\%)

Portugal

4.33

0.30

Netherlands

3.05

2.36

Austria

2.92

0.94

Spain

2.61

0.68

France

2.34

Finland

2.31

0.73

Greece

2.25

Italy

1.77

Belgium

1.73

Denmark

1.63

Ireland

1.60

1.12

1.29

Note: Vacancy rates are for the year 2000. For some countries information on vacancies is missing. Source: OECD, own calculations. 
Table A2: Regression Results for Quit Decision - Full Specification of Linear Probability Model.

\begin{tabular}{|c|c|c|c|c|c|c|c|c|c|c|c|c|c|c|c|c|c|}
\hline \multirow{3}{*}{$\begin{array}{l}\text { Linear Probability Model } \\
\text { Job Satisfaction (Standardized) }\end{array}$} & \multicolumn{3}{|c|}{ Austria } & \multicolumn{3}{|c|}{ Belgium } & \multicolumn{3}{|c|}{ Denmark } & \multicolumn{2}{|c|}{ Finland } & \multicolumn{3}{|c|}{ France } & \multicolumn{3}{|c|}{ Greece } \\
\hline & Coef. & s.e. & & Coef. & s.e. & & Coef. & s.e. & & Coef. & s.e. & Coef. & s.e. & & Coef. & s.e. & \\
\hline & -0.007 & 0.003 & $* * *$ & -0.009 & 0.003 & $* * *$ & -0.018 & 0.005 & $* * *$ & -0.014 & $0.005 * * *$ & -0.005 & 0.002 & $* *$ & 0.001 & 0.002 & \\
\hline Tenure & -0.0002 & 0.00004 & $* * *$ & -0.0002 & 0.0001 & $* * *$ & -0.0004 & 0.0001 & $* * *$ & -0.0004 & $0.0001 * * *$ & -0.0002 & 0.00003 & $* * *$ & -0.0002 & 0.00004 & $* * *$ \\
\hline Age & -0.006 & 0.004 & & -0.008 & 0.005 & $*$ & -0.010 & 0.006 & $*$ & 0.005 & 0.007 & 0.001 & 0.003 & & -0.002 & 0.004 & \\
\hline Age Squared & 0.0001 & 0.0000 & & 0.0001 & 0.0001 & & 0.0001 & 0.0001 & & -0.0001 & 0.0001 & 0.000 & 0.000 & & 0.000 & 0.000 & \\
\hline Couple & 0.002 & 0.007 & & 0.011 & 0.009 & & 0.008 & 0.012 & & 0.017 & 0.013 & 0.013 & 0.005 & $* *$ & -0.003 & 0.010 & \\
\hline Number of Children & -0.002 & 0.005 & & -0.008 & 0.007 & & -0.002 & 0.009 & & 0.006 & 0.010 & -0.003 & 0.004 & & 0.004 & 0.007 & \\
\hline Private Job & 0.014 & 0.005 & $* * *$ & 0.015 & 0.005 & $* * *$ & 0.026 & 0.008 & $*$ & 0.028 & $0.008 * * *$ & 0.011 & 0.004 & $* * *$ & 0.022 & 0.005 & $* * *$ \\
\hline Industry & -0.008 & 0.016 & & -0.075 & 0.066 & & 0.008 & 0.023 & & -0.036 & 0.034 & -0.020 & 0.019 & & -0.058 & 0.047 & \\
\hline Services & 0.000 & 0.016 & & -0.075 & 0.067 & & 0.031 & 0.023 & & -0.025 & 0.034 & -0.016 & 0.019 & & -0.057 & 0.047 & \\
\hline Regional Unemployment Rate (a) & 0.003 & 0.001 & & 0.000 & 0.001 & & -0.100 & 0.079 & & -0.005 & $0.002 * * *$ & -0.002 & 0.001 & $* * *$ & & & \\
\hline Number of Groups & \multicolumn{3}{|c|}{1,298} & \multicolumn{3}{|c|}{1,146} & \multicolumn{3}{|c|}{1,047} & \multicolumn{2}{|r|}{1,131} & \multicolumn{3}{|c|}{1,844} & \multicolumn{3}{|c|}{1,384} \\
\hline \multirow[t]{2}{*}{ Number of Observations } & \multicolumn{3}{|c|}{ 4,328 } & \multicolumn{3}{|c|}{ 3,313 } & \multicolumn{3}{|c|}{3,597} & \multicolumn{2}{|r|}{2,203} & \multicolumn{3}{|c|}{7,204} & \multicolumn{3}{|c|}{4,564} \\
\hline & \multicolumn{3}{|c|}{ Ireland } & \multicolumn{3}{|c|}{ Italy } & \multicolumn{3}{|c|}{ Netherlands } & \multicolumn{2}{|c|}{ Portugal } & \multicolumn{3}{|c|}{ Spain } & \multicolumn{3}{|c|}{ UK } \\
\hline Linear Probability Model & Coef. & s.e. & & Coef. & s.e. & & Coef. & s.e. & & Coef. & s.e. & Coef. & s.e. & & Coef. & s.e. & \\
\hline Job Satisfaction (Standardized) & -0.011 & 0.004 & $* * *$ & -0.002 & 0.002 & & -0.005 & 0.002 & $* *$ & 0.000 & 0.002 & -0.006 & 0.002 & $* * *$ & -0.023 & 0.005 & $* * *$ \\
\hline Tenure & -0.0004 & 0.0001 & $* * *$ & -0.0002 & 0.00003 & $* *$ & -0.0003 & 0.00003 & $* * *$ & -0.0003 & $0.00003 * * *$ & -0.0003 & 0.00004 & $* * *$ & -0.001 & 0.0001 & $* * *$ \\
\hline Age & -0.008 & 0.006 & & -0.004 & 0.003 & & -0.016 & 0.004 & $* * *$ & -0.001 & 0.003 & -0.008 & 0.003 & $* *$ & 0.005 & 0.007 & \\
\hline Age Squared & 0.0001 & 0.0001 & & 0.0001 & 0.00003 & & 0.0002 & 0.00005 & $* * *$ & 0.000 & 0.000 & 0.0001 & 0.00004 & $* *$ & -0.0001 & 0.0001 & \\
\hline Couple & 0.001 & 0.012 & & -0.002 & 0.006 & & 0.003 & 0.009 & & 0.006 & 0.007 & -0.005 & 0.007 & & 0.011 & 0.014 & \\
\hline Number of Children & 0.006 & 0.010 & & 0.005 & 0.004 & & 0.000 & 0.005 & & -0.004 & 0.004 & 0.009 & 0.004 & $*$ & -0.014 & 0.012 & \\
\hline Private Job & 0.025 & 0.007 & $* * *$ & 0.009 & 0.003 & $* * *$ & 0.013 & 0.005 & $* * *$ & 0.015 & $0.004 * * *$ & 0.013 & 0.004 & $* * *$ & 0.024 & 0.013 & $*$ \\
\hline Industry & 0.029 & 0.011 & $*$ & 0.010 & 0.007 & & 0.024 & 0.016 & & 0.011 & 0.010 & -0.027 & 0.017 & & -0.094 & 0.051 & \\
\hline Services & 0.039 & 0.012 & $* * *$ & 0.010 & 0.007 & & 0.036 & 0.017 & $* *$ & 0.009 & 0.010 & -0.026 & 0.017 & & -0.069 & 0.051 & $*$ \\
\hline Regional Unemployment Rate (a) & 0.006 & 0.004 & & -0.001 & 0.0002 & $* * *$ & & & & 0.001 & 0.001 & -0.0003 & 0.0004 & & 0.003 & 0.003 & \\
\hline Number of Groups & & 983 & & & 2,640 & & & 2,296 & & & 1,872 & & 2,096 & & & 1,466 & \\
\hline Number of Observations & & 2,981 & & & 9,483 & & & 8,143 & & & 6,682 & & 6,836 & & & 5,350 & \\
\hline
\end{tabular}

(a) Estimates for the regional unemployment rate are missing for The Netherlands. For The Netherlands overall unemployment rates are available, but regional information is not available in ECHP.

Notes: A $* * * / * * * *$ indicates that the coefficient is different from zero at a $11 \% / 5 \mid \% / 10 \nmid \%$ level of significance. All regressions include time and education dummies (not presented). 
Table A3: Regression Results for Job Satisfaction - Full Specification of Linear Probability Model.

\begin{tabular}{|c|c|c|c|c|c|c|c|c|c|c|c|c|c|c|c|c|c|c|}
\hline \multirow{3}{*}{$\begin{array}{l}\text { Linear Probability Model } \\
\text { Quit }\end{array}$} & \multicolumn{3}{|c|}{ Austria } & \multicolumn{3}{|c|}{ Belgium } & \multicolumn{3}{|c|}{ Denmark } & \multicolumn{3}{|c|}{ Finland } & \multicolumn{3}{|c|}{ France } & \multicolumn{3}{|c|}{ Greece } \\
\hline & Coef. & s.e. & & Coef. & s.e. & & Coef. & s.e. & & Coef. & s.e. & & Coef. & s.e. & & Coef. & s.e. & \\
\hline & 0.318 & 0.108 & $* * *$ & 0.338 & 0.122 & $* * *$ & 0.164 & 0.088 & $*$ & 0.403 & 0.100 & $* * *$ & 0.390 & 0.084 & $* * *$ & 0.198 & 0.122 & \\
\hline Tenure & 0.0002 & 0.0004 & & -0.0001 & 0.0004 & & -0.0004 & 0.0004 & & -0.0005 & 0.0005 & & 0.0004 & 0.0003 & & 0.0006 & 0.0003 & $* *$ \\
\hline Age & -0.023 & 0.033 & & -0.082 & 0.039 & $* *$ & -0.085 & 0.036 & $* *$ & 0.029 & 0.046 & & -0.009 & 0.028 & & 0.069 & 0.032 & $* *$ \\
\hline Age Squared & 0.0002 & 0.0004 & & 0.001 & 0.000 & $* *$ & 0.001 & 0.0004 & $* *$ & -0.0003 & 0.0006 & & 0.0001 & 0.0003 & & -0.001 & 0.0004 & $* *$ \\
\hline Couple & 0.098 & 0.065 & & 0.104 & 0.081 & & 0.168 & 0.079 & $* *$ & 0.146 & 0.093 & & -0.046 & 0.060 & & -0.001 & 0.069 & \\
\hline Number of Children & -0.024 & 0.052 & & 0.000 & 0.054 & & -0.046 & 0.060 & & -0.010 & 0.076 & & -0.057 & 0.045 & & 0.022 & 0.048 & \\
\hline Private Job & -0.131 & 0.056 & $* *$ & -0.071 & 0.059 & & -0.013 & 0.062 & & 0.024 & 0.076 & & -0.191 & 0.045 & & -0.264 & 0.046 & $* * *$ \\
\hline Industry & 0.010 & 0.265 & & 0.201 & 0.229 & & -0.324 & 0.175 & $*$ & -0.101 & 0.162 & & -0.222 & 0.202 & & 0.151 & 0.241 & \\
\hline Services & 0.039 & 0.261 & & 0.132 & 0.229 & & -0.333 & 0.173 & $*$ & 0.078 & 0.163 & & -0.193 & 0.201 & & 0.204 & 0.240 & \\
\hline Regional Unemployment Rate (a) & -0.014 & 0.015 & & -0.031 & 0.009 & $* * *$ & 0.476 & 0.189 & $* *$ & 0.006 & 0.011 & & 0.006 & 0.009 & & -0.073 & 0.035 & $* *$ \\
\hline Number of Groups & \multicolumn{3}{|c|}{1,276} & \multicolumn{3}{|c|}{1,143} & \multicolumn{3}{|c|}{1,014} & \multicolumn{3}{|c|}{966} & \multicolumn{3}{|c|}{1,815} & \multicolumn{3}{|c|}{1,268} \\
\hline \multirow[t]{2}{*}{ Number of Observations } & \multicolumn{3}{|c|}{4,310} & \multicolumn{3}{|c|}{3,120} & \multicolumn{3}{|c|}{3,562} & \multicolumn{3}{|c|}{1,665} & \multicolumn{3}{|c|}{7,149} & \multicolumn{3}{|c|}{4,360} \\
\hline & \multicolumn{3}{|c|}{ Ireland } & \multicolumn{3}{|c|}{ Italy } & \multicolumn{3}{|c|}{ Netherlands } & \multicolumn{3}{|c|}{ Portugal } & \multicolumn{3}{|c|}{ Spain } & \multicolumn{3}{|c|}{ UK } \\
\hline Linear Probability Model & Coef. & s.e. & & Coef. & s.e. & & Coef. & s.e. & & Coef. & s.e. & & Coef. & s.e. & & Coef. & s.e. & \\
\hline Quit & 0.189 & 0.107 & $*$ & 0.234 & 0.090 & $* * *$ & 0.174 & 0.069 & $* *$ & 0.183 & 0.094 & $*$ & 0.221 & 0.111 & $* *$ & 0.088 & 0.052 & $*$ \\
\hline Tenure & 0.0002 & 0.0004 & & 0.001 & 0.0003 & ** & 0.0005 & 0.0002 & $* *$ & 0.0005 & 0.0003 & & 0.0004 & 0.0003 & & -0.001 & 0.0004 & $* * *$ \\
\hline Age & -0.082 & 0.038 & $* *$ & -0.039 & 0.025 & & -0.027 & 0.024 & & -0.096 & 0.026 & $* * *$ & -0.023 & 0.027 & & -0.017 & 0.029 & \\
\hline Age Squared & 0.001 & 0.0005 & $* *$ & 0.0004 & 0.0003 & & 0.0003 & 0.0003 & & 0.001 & 0.0003 & $* * *$ & 0.0003 & 0.0003 & & 0.0002 & 0.0004 & \\
\hline Couple & 0.123 & 0.092 & & 0.039 & 0.055 & & 0.146 & 0.060 & ** & 0.226 & 0.062 & $* * *$ & -0.014 & 0.056 & & -0.084 & 0.062 & \\
\hline Number of Children & -0.005 & 0.060 & & -0.007 & 0.039 & & -0.047 & 0.036 & & -0.031 & 0.040 & & 0.037 & 0.037 & & 0.097 & 0.047 & $* *$ \\
\hline Private Job & -0.174 & 0.070 & $* *$ & -0.161 & 0.039 & $* * *$ & -0.016 & 0.039 & & -0.224 & 0.047 & $* * *$ & -0.061 & 0.041 & & -0.066 & 0.058 & \\
\hline Industry & -0.121 & 0.134 & & -0.046 & 0.121 & & -0.212 & 0.178 & & -0.112 & 0.100 & & -0.033 & 0.118 & & -0.259 & 0.196 & \\
\hline Services & -0.233 & 0.132 & $*$ & 0.070 & 0.119 & & -0.185 & 0.178 & & 0.074 & 0.099 & & 0.067 & 0.118 & & -0.310 & 0.197 & \\
\hline Regional Unemployment Rate (a) & 0.021 & 0.036 & & -0.009 & 0.002 & $* * *$ & & & & 0.038 & 0.009 & $* * *$ & 0.008 & 0.004 & $* *$ & -0.003 & 0.015 & \\
\hline Number of Groups & & 947 & & & 2,512 & & & 2,265 & & & 1,769 & & & 1,934 & & & 1,470 & \\
\hline Number of Observations & & 2,903 & & & 9,098 & & & 7,986 & & & 6,340 & & & 6,607 & & & 5,464 & \\
\hline
\end{tabular}

(a) Estimates for the regional unemployment rate are missing for The Netherlands. For The Netherlands overall unemployment rates are available, but regional information is not available in ECHP.

Notes: A $* * * / * * / *$ indicates that the coefficient is different from zero at a $1 \% / 5 \mid \% / 10 / \%$ level of significance. All regressions include time and education dummies (not presented). 


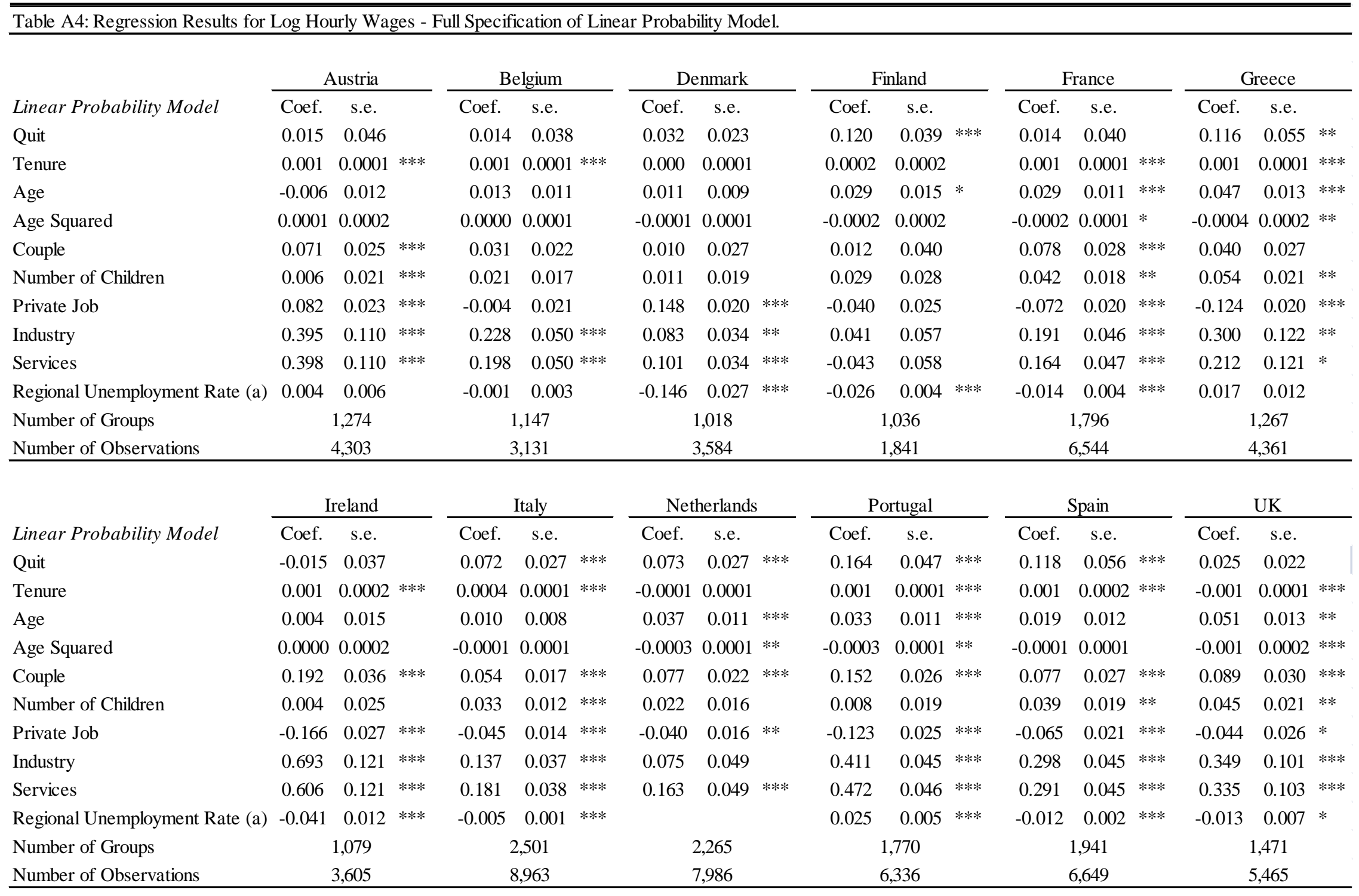

(a) Estimates for the regional unemployment rate are missing for The Netherlands. For The Netherlands overall unemployment rates are available, but regional information is not available in ECHP.

Notes: A ***/**/* indicates that the coefficient is different from zero at a 11\%/5|\%/101\% level of significance. All regressions include time and education dummies (not presented). 